Case report

\title{
DESCRIPTION OF AN ANAPLASTIC RHABDOMYOSARCOMA IN A COCKATIEL (NYMPHICUS HOLLANDICUS)
}

\author{
OBER Ciprian ${ }^{1}$, GAL Adrian Florin²*, MICLĂUŞ Viorel ${ }^{3}$, PEŞTEAN Cosmin ${ }^{1}$, \\ TAULESCU Marian ${ }^{2}$, BEL Lucia ${ }^{1}$, CĂTOI Cornel ${ }^{2}$, OANĂ Liviu ${ }^{1}$
}

${ }^{1}$ Department of Propedeutics and Surgical Techniques, Faculty of Veterinary Medicine, University of Agricultural Sciences and Veterinary Medicine Cluj-Napoca, Calea Mănăştur 3-5, Cluj-Napoca, 400372, Romania; ${ }^{2}$ Department of Pathologic Anatomy, Necropsy and Veterinary Forensic Medicine, Faculty of Veterinary Medicine, University of Agricultural Sciences and Veterinary Medicine Cluj-Napoca, Calea Mănăştur 3-5, Cluj-Napoca, 400372, Romania; ${ }^{3}$ Department of Histology, Faculty of Veterinary Medicine, University of Agricultural Sciences and Veterinary Medicine Cluj-Napoca, Calea Mănăştur 3-5, Cluj-Napoca, 400372, Romania

(Received $18^{\text {th }}$ February; Accepted $20^{\text {th }}$ May 2015)

\begin{abstract}
Rhabdomyosarcoma is a malignant tumor of the skeletal muscles that is occasionally observed in free-living and pet birds. A case of malignant rhabdomyosarcoma in the musculature of the right wing of a captive female cockatiel (Nymphicus bollandicus) was investigated. The clinical aspect and radiographic images suggested an invasive neoplasm. Histologically, the tumor was composed of a patternless array of large primitive polygonal cells or sheets of bizarre cells with giant nuclei and atypical mitoses set in a collagenous stroma. Anaplastic cells were poorly differentiated and exhibited notable cellular and nuclear pleomorphism. Nuclei showed extreme variability in number, size, shape, chromatin distribution and nucleolar size and number. The cross striations were encountered in elongated multinucleated cells known as "strap cells" and in ovoid cells known as "racquet cells" and numerous mitotic figures were also observed. Neoplastic cells were positive for muscle actin and negative for desmin, suggesting the diagnosis of anaplastic rhabdomyosarcoma. It is the first reliable record of a rhabdomyosarcoma in a cockatiel (Nymphicus hollandicus) in Romania.
\end{abstract}

Key words: anaplastic rhabdomyosarcoma, cockatiel, immunohistochemistry, neoplasm, wing

\section{INTRODUCTION}

Rhabdomyosarcoma (RMS) is a malignant tumor with its origin in the striated and skeletal muscles. In free-living and pet birds, this type of tumor is only occasionally observed [1,2]. It is well known that, especially in budgerigars, neoplastic diseases have a high incidence [3]. A predilection site for rhabdomyosarcoma is not observed [4], but the tumor has been reported in the wing, shoulder, dorsal lumbar region or retrobulbary

\footnotetext{
*Corresponding author: e-mail: adrian.gal@usamvcluj.ro
} 
[2,5-9]. These tumors are composed of a pleomorphic population of fusiform to elongated cells. Although the histopathological findings reveal sometimes cytoplasmic cross-striations, confirmation of the tumor requires the use of immunohistochemistry or electron microscopy [1].

The present study reports a RMS tumor in a cockatiel (Nymphicus hollandicus) in the musculature of the right wing. To our knowledge this is the first description of an anaplastic rhabdomyosarcoma in a cockatiel in Romania.

\section{CASE PRESENTATION}

\section{Case history}

An adult female cockatiel (Nymphicus hollandicus) was presented at the University of Agricultural Sciences and Veterinary Medicine Cluj-Napoca, Faculty of Veterinary Medicine, with an ulcerated, black colored mass on the caudal part of the right wing (Figure 1). Despite the invasivity of the tumor at the level of the distal humerus, proximal ulna and radius regions, the general clinical status of the bird was good. The lateral radiographic examination showed an opaque invasive mass in the muscle of the suggested regions. Surgical excision was performed with the owner's permission, but the bird was humanely euthanized due to the invasive aspect of the tumor. Complete necropsy was performed at the Laboratory of Pathologic Anatomy at the Faculty of Veterinary Medicine Cluj-Napoca, Romania. Necropsy confirmed the extremely invasive tumor that involved a large portion of the right wing, without metastases in other organs.

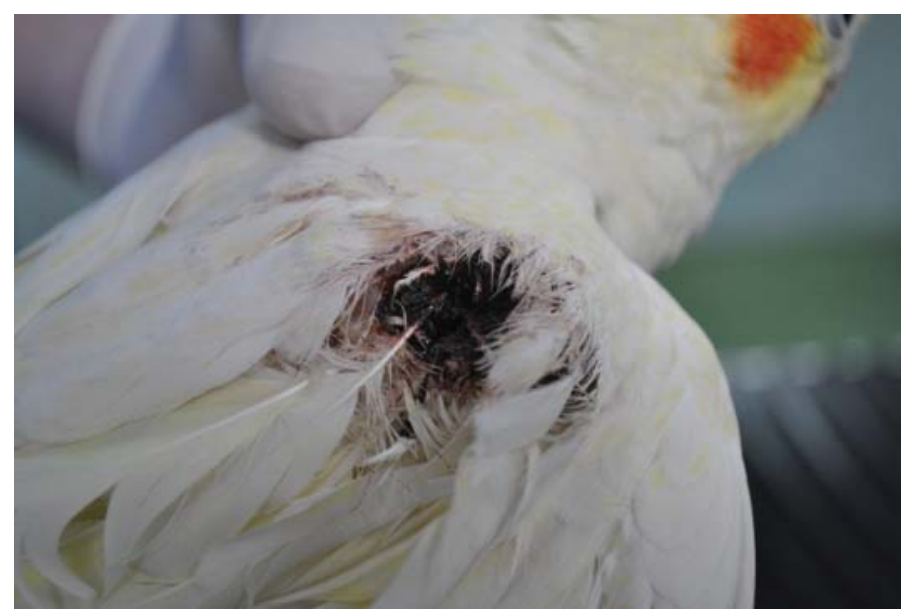

Figure 1. Clinical aspect of the tumoral mass

\section{Histopathology sampling}

From the tumoral mass, small pieces (cca. $0.5 \mathrm{~cm}$ ) were fixed in neutral $10 \%$ buffered formalin. Tissues were subsequently embedded in paraffin wax, sectioned at $5 \mu \mathrm{m}$, and 
stained with Haematoxylin-eosin (HE), Goldner's trichrome and ferric Heidenhaim hematoxylin methods. Tissue analysis was performed using an Olympus system for image acquisition and analysis, respectively an Olympus BX51 microscope equipped with Olympus Cell B software.

\section{Immunohistochemistry assessment}

Immunohistochemical staining methods for actin (mouse anti-human actin antibody, clone HHF-35, cat no MAK-0014, Linaris, Biologische Produkte, Dossenheim, Germany) and desmin (mouse anti-human desmin antibody, clone D33, cat no K057, Linaris, Biologische Produkte, Dossenheim, Germany), were performed on formalin-fixed, paraffin-embedded tissue sections (4- $\mu$ m-thickness). Leica Bond$\max ^{\mathrm{TM}}$ Immunohostochemistry system (Leica Biosystems Melbourne, Bond Max model, M2 12154 series) was used in order to detect the origin of tumoral cells. Briefly, the automatic Leica-system included the following steps: (1) deparaffinization and rinsing with EDTA solution at $\mathrm{pH} 8.8$ (Epitope Retrieval Solution 2) at $98^{\circ} \mathrm{C}$ for 20 minutes; (2) after rinsing, the DC 9800 kit was used for 10 minutes (Leica Microsystem $\mathrm{GmbH}$ ) in order to block the endogenous peroxidase; (3) rinsing, after which the "mouse anti-human actin" and "mouse anti-human desmin" primary antibodies were added (on separate slides) and incubated for 30 minutes; (4) polymerase adding and incubation for 10 minutes, obtaining the colored reaction with the help of DAB (Diaminobenzidine), respectively; (5) Mayer's haematoxylin counterstain. Concerning tumoral cells evaluation, cells with a labeled cytoplasm (i.e., different intensities of brown) were considered positive. However, negative and positive (i.e., unaffected skeletal muscle) control slides were used for high accuracy.

\section{Necropsy findings}

The bird was in a good body condition, but the right wing was partially affected by a dark mass $(2-1.5 \mathrm{~cm})$ that invaded the soft tissues (i.e., muscle, skin) of the distal humerus, radius and ulna regions. The joints and the bones were not affected. At necropsy a poorly-demarcated subcutaneous neoplasm was noted in this area. The tumor presented poorly defined borders, fixation to the skin and underlying muscle tissue, and ulcerations. No metastases in other organs were noticed.

\section{Histological and immunohistochemical description}

Microscopically, the mass was unencapsulated and composed of neoplastic cells having considerable morphologic variability. Anaplastic cells were poorly differentiated and exhibited prominent cellular and nuclear pleomorphism (Figure 2). Nuclei showed extreme variability in number, size, shape, chromatin distribution and nucleolar size and number. The neoplastic nuclei were disproportionately large relative to cell size, resulting in an increased nuclear to cytoplasmic ratio. The tumor consisted of a patternless array of large primitive polygonal cells or sheets of bizarre cells with giant 
nuclei and atypical mitoses set in a collagenous stroma. Nevertheless, the cells of the described anaplastic rhabdomyosarcoma had prominent nuclei and eosinophilic cytoplasm (i.e., rhabdomyoblasts). There were spindle-shaped multinucleate "strap cells" and ovoid "racquet cells". Cross striations were encountered in elongated multinucleated cells (Figure 3). Numerous mitotic figures were observed.

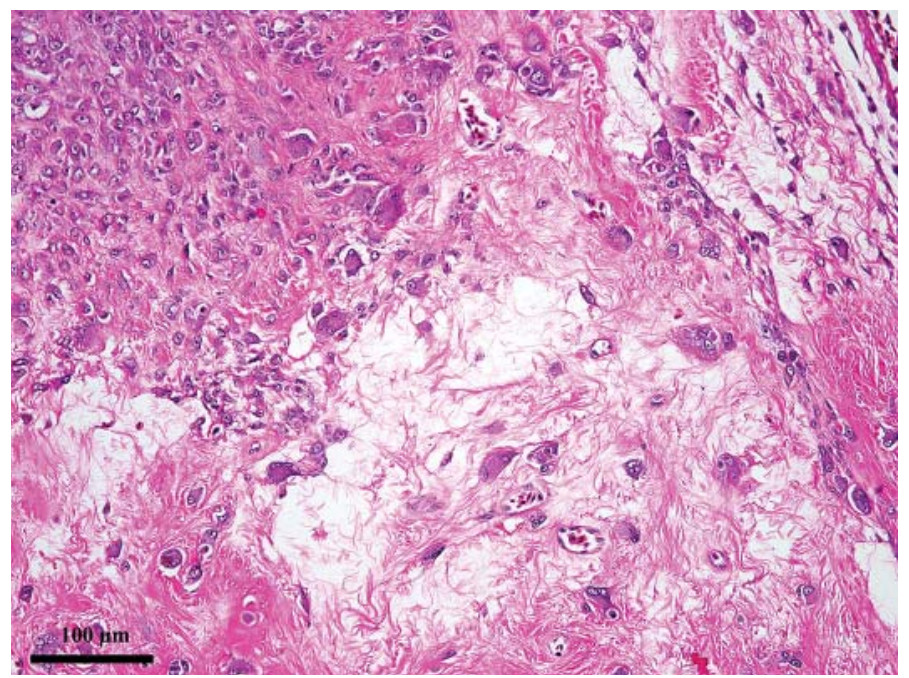

Figure 2. Poorly differentiated neoplastic lesion, showing cell pleomorphism and anisokaryosis. Hematoxylin-eosin stain

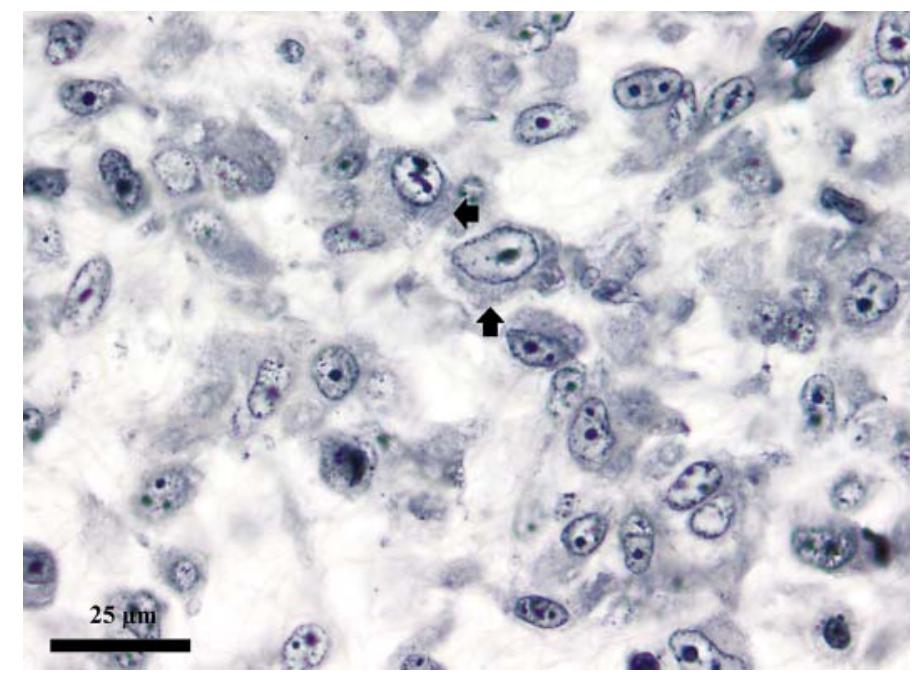

Figure 3. Tumoral cells showing cross striations in the cytoplasm. Ferric Heidenhaim hematoxylin stain

Immunohistochemically, neoplastic cells were positive for muscle actin, but negative for desmin (Figure 4). Immunostaining for actin was homogeneous and intense in a good number of tumoral cells $(83.43 \%$ positive tumoral cells), while immunostaining 
for desmin was absent in the tumor cells but was strongly positive in control tissues (Figure 5).

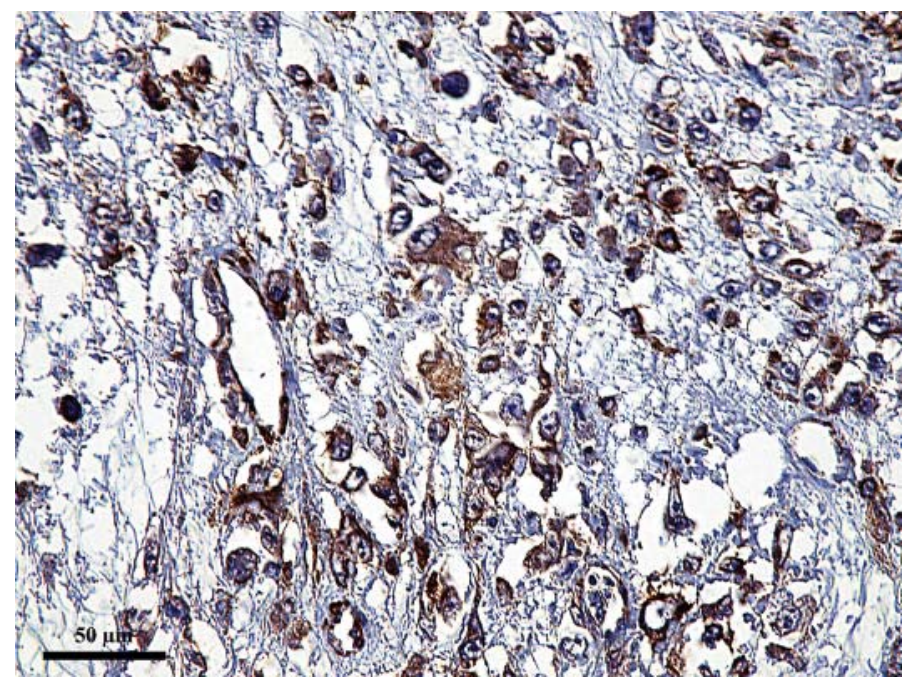

Figure 4. Positive immunolabelling for muscular actin in most tumoral cells. Immunohistochemical reaction and Mayer's haematoxylin counterstain

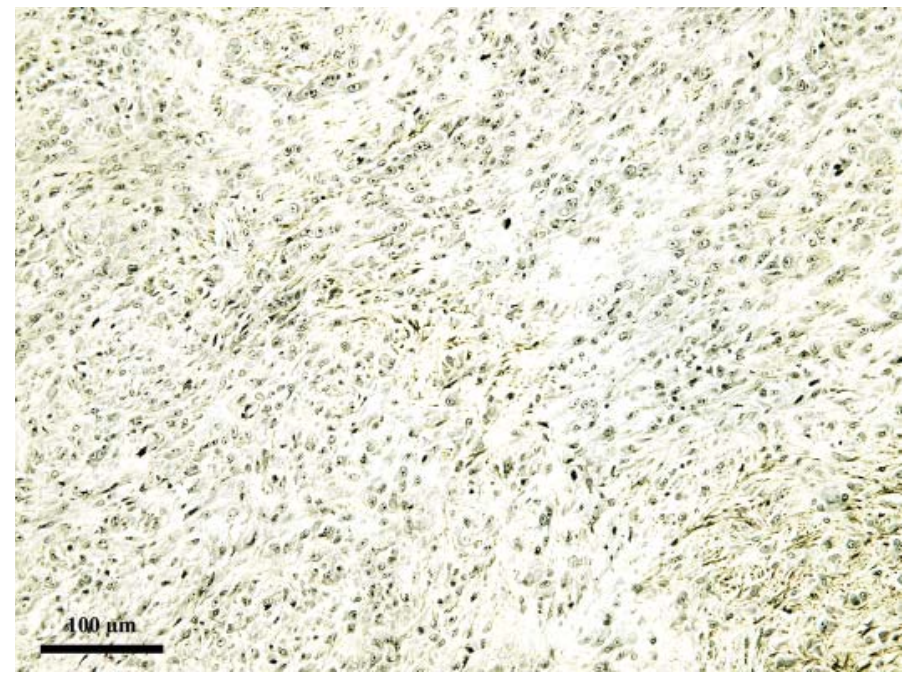

Figure 5. Negative immunolabelling for desmin in tumoral cells. Immunohistochemical reaction and Mayer's haematoxylin counterstain

\section{DISCUSSION}

Several recent reports utilized immunohistochemistry like the ideal diagnostic technique for confirmation of the diagnosis of rhabdomyosarcoma [10].

In our study, the histopathological examination was highly suggestive, since some neoplastic cells showed some typical features for rhabdomyosarcoma (i.e., cytoplasmic 
cross-striations visible in histologic sections stained by $\mathrm{HE}$ and ferric Heidenhaim hematoxylin methods; the occurrence of elongated multinucleated cells, some of them showing aspects known as "strap" and "racquet" cells). In a similar manuscript, Manarolla et al. (2008) described similar histological details for a pectoral rhabdomyosarcoma. They described the tumour as composed of spindle cells with indistinct cell borders, marked anisocytosis and anisokaryosis, a high nuclear to cytoplasmic ratio, and a moderate amount of eosinophilic cytoplasm. Few multinucleated giant cells were also observed [11]. In another report, Fernández-Bellon et al. (2003) mention a highly cellular, poorly demarcated, unencapsulated invasive sarcoma. In contrast to our histological findings, they did not find cross striations in the cytoplasm of tumoral cells [1].

However, differential diagnosis of rhabdomyosarcoma includes poorly differentiated sarcomas such as fibrosarcoma, leiomyosarcoma or schwannoma, but in the last ones the cross striations cannot be detected in the cytoplasm. In order to establish the final diagnosis, the immunohistochemical reaction is mandatory [1]. Fernandez-Bellon et al. (2003) found positive immunostaining for muscle actin, vimentin and myoglobin in a rhabdomyosarcoma of a pigeon, but neoplastic cells were negative for desmin. Desmin and myoglobin are basic markers for striated muscle cell tumors [10]. However, desmin may be unnoticeable in the poorly differentiated rhabdomyosarcoma [1]. In another paper, Gulbahar et al. (2005) described a rhabdomyosarcoma where tumor cells were positive for desmin, vimentin and alpha-smooth muscle actin [9].

Concerning the $\alpha$-smooth muscle actin, rare positive immunostaining is not surprising in rhabdomyosarcoma [9-11]. The biomarkers are variably expressed depending upon the grade of differentiation of neoplastic cells [10,11]. The uneven staining for actin could be due to the heterogeneity of neoplastic cells. Well differentiated tumoral cells are positive for actin, whereas cells negative for actin are rather more anaplastic.

In our case, the negative staining for desmin and positive staining for actin in tumoral cells presented a possible difference in respect with other cases described [9]. On the other hand, similar to our case, Fernandez-Bellon et al. (2003) described comparable results concerning expression of actin and desmin biomarkers in an avian rhabdomyosarcoma [1]. The uneven expression of some specific biomarkers in avian rhabdomyosarcomas could be due to the degree of differentiation of the rhabdomyocytes [1,9-11].

We can conclude that the histologic and immunohistochemical features of the tumor were significant for the diagnosis of the anaplastic rhabdomyosarcoma. To our knowledge, there are no existing reports of anaplastic rhabdomyosarcoma in a cockatiel (Nymphicus hollandicus) or other captive birds in Romania.

\section{Acknowledgements}

This paper was published under the frame of European Social Fund, Human Resources Development Operational Program 2007-2013, project no. POSDRU /159/ 1.5/S/ 136893. 


\section{REFERENCES}

1. Fernandez-Bellon H, Martorell J, Rabanal R, Ramis A: Rhabdomyosarcoma in a racing pigeon (Columba livia). Avian Pathol 2003, 32:613-616.

2. Maluenda AC, Casagrande RA, Kanamura CT, Torres LN, Quagglia Neto F, Gomes MS, Matushima ER: Rhabdomyosarcoma in a yellow-headed caracara (Milvago chimachima). Avian Dis 2010, 54(2):951-954.

3. Reece RL: Observations on naturally occurring neoplasms in birds in the state of Victoria. Australia. Avian Pathol 1992, 21:3-32.

4. Schmidt RE, Reavill DR, Phalen DN: Pathology of Pet and Aviary Birds. Iowa, IA, Iowa State Press; 2003, 153.

5. Frost C: Experiences with pet budgerigars. Vet Rec 1961, 73:621-626.

6. Beach JE: Diseases of budgerigars and other cage birds. Part III. Vet Rec 1962, 74:136-137.

7. Blackmore DK: The pathology and incidence of neoplasia in cage birds. J Small Anim Pract 1965, 6:217-223.

8. Raphael BL, Nguyen HT: Metastasizing rhabdomyosarcoma in a budgerigar. J Am Vet Med Assoc 1980, 177:925-926.

9. Gulbahar MY, Ozak A, Guvenc T, Yarim M: Retrobulbar rhabdomyosarcoma in a budgerigar (Melopsittacus undulates). Avian Pathol 2005, 34:486-488.

10. Cooper BJ, Valentine BA: Tumors of muscle, in Meuten DJ (ed): Tumors in Domestic Animals. Iowa, IA, Iowa State Press $4^{\text {th }} ; 2002,319-363$.

11. Manarolla G, Radaelli E, Pisoni G, Sironi G, Rampin T: Rhabdomyosarcoma of the pectoral muscles of a free-living European robin (Erithacus rubecula). Avian Pathol 2008, 37(3): 311 314.

\section{OPIS ANAPLASTIČNOG RABDOMIOSARKOMA KOD NIMFE (NYMPHICUS HOLLANDICUS)}

OBER Ciprian, GAL Adrian Florin, MICLĂUŞ Viorel, PEŞTEAN Cosmin, TAULESCU Marian, BEL Lucia, CĂTOI Cornel, OANĂ Liviu

Rabdomiosarkom je maligni tumor skeletnih mišića koji se povremeno uočava kod ptica. Ispitivan je slučaj malignog rabdomiosarkoma muskulature desnog krila ženke nimfe (Nymphicus hollandicus). Klinički aspekt i rendgenski nalaz ukazuju na invazivnu neoplazmu. Histološki tumor se sastoji od niza velikih primitivnih poligonalnih ćelija ili ploča bizarnih ćelija sa džinovskim jedrima i atipičnim mitozama smeštenih u kolagenoj stromi. Anaplastične ćelije su bile slabo diferentovane sa izrazitim ćelijskim i nuklearnim pleomorfizmom. Jedra su bila izuzetno raznolika po brojnosti, veličini, obliku i distribuciji hromatina kao i veličini i broju jedaraca. Poprečne pruge su uočene kod izduženih višejedarnih ćelija poznatih kao "strap ćelije" i kod jajolikih ćelija znanih kao racquet ćelije. Takođe su bile prisutne brojne mitotičke figure. Neoplastične ćelije bile su pozitivne na mišićni aktin i negativne na dezmin, što ukazuje na dijagnozu anaplastičnog rabdomiosarkoma. Ovo predstavlja prvi pouzdani dokaz rabdomiosarkoma nimfe (Nymphicus hollandicus) na području Rumunije. 